\title{
Pemanfaatan Protein pada Ayam Broiler yang Diberi Ransum Menggunakan Kalsium Mikropartikel Cangkang Telur dengan Suplementasi Asam Sitrat
}

\section{Protein Utilization in Broiler Chicken Fed Diet Composed of Eggshell Microparticle Calcium with Citric Acid Supplementation}

\author{
Hudhaya Eka Santia, Nyoman Suthama dan Bambang Sukamto \\ Fakultas Peternakan dan Pertanian Universitas Diponegoro Semarang \\ Jln. Drh R. Soejono Koesoemowardojo, Tembalang, Kota Semarang 50275 \\ Corresponding e-mail: hudhayaekas@gmail.com
}

\begin{abstract}
The aim of this research was to evaluate the effect of dietary microparticle organic-calcium derived from eggshell with citric acid addition as an acidifier on protein digestibility, meat calcium mass and meat protein mass in broiler chicken. A total of 160 broilers aged 15 days old of Cobb strain with initial body weight of $413.10 \pm 11.85 \mathrm{~g}$ were used in the present study. Experiment was assigned in a completely randomized design with 5 treatments and 4 replications, experimental unit consisted of 8 chicks. Experimental feeds applied, namely T0 (control feed), T1 (18\% protein feed), T2 (18\% protein feed composed of microparticle Ca), T3 (18\% protein feed $+1.2 \%$ citric acid), and T4 (18\% protein feed composed of microparticle $\mathrm{Ca}+1,2 \%$ citric acid). Parameters observed were protein digestibility, meat calcium mass, and meat protein mass. Data were subjected to analysis of variance and continued to Duncan's Multiple Range test (DMRT). The results indicated that dietary inclusion of microparticle organic-calcium in $18 \%$ protein feed with citric acid addition (T4) significantly $(\mathrm{P}<0.05)$ increased protein digestibility and meat protein mass with the highest value was $89.43 \%$ and $46.37 \mathrm{~g}$, respectively, but the highest meat $\mathrm{Ca}$ mass was in $\mathrm{T} 0(9.76 \mathrm{~g})$. Based on the results of this study it can be concluded that dietary protein utilization can be categorized effective in broiler feed $18 \%$ protein diet composed of microparticle organic-calcium supplemented with citric acid as acidifier.
\end{abstract}

Key words: protein digestibility, meat calcium mass, meat protein mass, acidifier, broiler

\begin{abstract}
ABSTRAK
Penelitian bertujuan untuk mengkaji pengaruh penggunaan kalsium organik mikropartikel dari cangkang telur dalam ransum dengan tambahan asam sitrat sebagai acidifier terhadap kecernaan protein, massa kalsium dan massa protein daging pada ayam broiler. Ternak yang digunakan adalah ayam broiler strain Cobb umur 15 hari sebanyak 160 ekor dengan bobot badan 413.10 $\pm 11.85 \mathrm{~g}$. Penelitian disusun dalam rancangan acak lengkap (RAL) dengan 5 perlakuan dan 4 ulangan dengan setiap perlakuan masing-masing 8 ekor. Perlakuan yang diberikan yaitu T0 (ransum kontrol), T1 (ransum dengan protein 18\%), T2 (ransum dengan protein 18\% menggunakan Ca mikropartikel), T3 (ransum dengan protein 18\% + asam sitrat 1,2\%), dan T4 (ransum dengan protein $18 \%$ menggunakan Ca mikropartikel + asam sitrat 1,2\%). Parameter yang diamati adalah kecernaan protein, massa kalsium (Ca) daging, dan massa protein daging. Data diolah statistik dengan analisis ragam dan dilanjutkan dengan uji ganda Duncan. Hasil penelitian menunjukkan bahwa dalam ransum $18 \%$ protein dengan penggunaan kalsium organik mikropartikel dan tambahan asam sitrat $(\mathrm{T} 4)$ nyata $(\mathrm{P}<0,05)$ meningkatkan kecernaan protein dan massa protein daging dengan nilai tertinggi masing-masing $89.43 \%$ dan $46.37 \mathrm{~g}$, tetapi massa Ca daging paling tinggi pada perlakuan ransum kontrol (T0) (9.76g). Berdasarkan hasil penelitian dapat disimpulkan bahwa pemanfaatan protein ransum dapat dikategorikan efektif pada broiler yang diberi $18 \%$ protein ransum menggunakan kalsium organik mikropartikel dengan suplementasi asam sitrat sebagai acidifier.
\end{abstract}

Kata kunci: kecernaan protein, massa kalsium daging, massa protein daging, acidifier, broiler

\section{PENDAHULUAN}

Ayam broiler merupakan komoditas ternak unggas yang banyak dibudidayakan di Indonesia yang memiliki kemampuan tinggi dalam mengubah ransum menjadi daging secara efektif. Ayam broiler adalah jenis unggas unggul merupakan hasil persilangan dari bangsa ayam yang mempunyai performa produksi daging tinggi (Zuraida et al., 
2006). Pertumbuhan ayam broiler cepat karena telah mengalami perbaikan genetik hasil pemuliabiakkan dan didukung oleh faktor lingkungan dan kesesuaian kebutuhan nutrisi. Daging ayam merupakan sumber protein hewani dengan harga yang lebih terjangkau dibandingkan dengan daging asal ternak lainnya, terutama ternak besar. Upaya peningkatan efisiensi produksi ayam broiler, baik kuantitas maupun kualitas perlu diupayakan melalui modifikasi ransum. Upaya yang dilakukan pada penelitian ini yaitu dengan penambahan asam sitrat sebagai acidifier pada ransum protein rendah menggunakan tepung cangkang telur yang dibuat mikropartikel.

Asam sitrat merupakan asam organik yang bermanfaat sebagai acidifier yang dapat mengasamkan saluran pencernaan sehingga menurunkan $\mathrm{pH}$, mempengaruhi laju digesta dan mengurangi populasi bakteri patogen yang berdampak positif terhadap kesehatan saluran pencernaan dan peningkatan kecernaan nutrien (Tolba, 2010; Yendy et al., 2014). Asam sitrat mampu meningkatkan bobot badan dan dapat memperbaiki konversi ransum (Jamilah et al., 2013). Penambahan asam organik pada ayam secara tidak langsung mampu meningkatkan fungsi dari enzim pencernaan yang berpengaruh terhadap peningkatan pencernaan dan bermuara pada penyerapan nutrien, terutama protein.

Penurunan $\mathrm{pH}$ usus halus akibat pemberian acidifier disamping dapat meningkatkan kecernaan dan penyerapan protein, juga kondusif bagi retensi kalsium (Ca). Penggunaan asam sitrat sebagai acidifier mampu meningkatkan penyerapan mineral (Yendy et al., 2014). Penyerapan dan transportasi mineral, terutama kalsium, selalu berhubungan dengan protein yang sering disebut $\mathrm{Ca}$ binding protein $(\mathrm{CaBP})$ (Mentari et al., 2014). Terbentuknya ikatan dan penyerapan CaBP lebih efektif dengan penggunaan tepung cangkang telur yang dibuat mikropartikel. Tepung cangkang telur merupakan kalsium organik yang mempunyai bioavailabilitas tinggi bagi ayam. Cangkang telur mengandung 3,3\% garam organik dan mengandung bahan anorganik berupa kalsium karbonat (CaCO3) sekitar 98,5\% dan Magnesium Karbonat (MgCO3) sekitar 0,85\% (Safitri et al., 2013).

Penelitian bertujuan untuk memanfaatkan limbah peternakan berupa cangkang telur sebagai sumber $\mathrm{Ca}$ organik yang dibuat mikropartikel dan mengkaji pengaruhnya berkaitan dengan penambahan asam sitrat sebagai acidifier. Efek kombinasi mikropartikel $\mathrm{Ca}$ cangkang telur dan asam sitrat diuji terhadap produktivitas ayam broiler ditinjau dari efisiensi penggunaan protein meliputi kecernaan protein, massa kalsium daging, dan massa protein daging.

\section{MATERI DAN METODE}

Penelitian menggunakan ayam broiler umur 15 hari strain Coob sebanyak 160 ekor

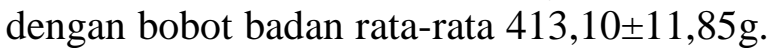
Ransum penelitian tersusun dari jagung giling, bekatul, bungkil kedelai, tepung ikan, tepung cangkang telur, $\mathrm{CaCO}_{3}$, premix dan asam sitrat sebagai acidifier. Komposisi ransum dengan kandungan nutrisi disajikan pada Tabel 1.

Kandang beralas sekam sebagai litter dilengkapi dengan pemanas berupa gasolek, kandang battery sebanyak 20 unit, tempat makan dan air minum, lampu bohlam 60 watt sebanyak 10 buah. Timbangan analitik untuk menimbang ayam dan ransum, hygrometer untuk mengukur suhu dan kelembaban dalam dan luar kandang, mortar dan lumpang untuk menghaluskan eksreta kering.

\section{Pelaksanaan Penelitian}

Penelitian ini diawali dengan pembuatan tepung cangkang. Cangkang telur yang didapat dari limbah pabrik roti dicuci bersih, kemudian dikeringkan di bawah sinar matahari selama 1-2 hari. Cangkang telur yang telah kering dihaluskan, selanjutnya diayak kemudian ditambah aquades dengan perbandingan 1:3 dan disonifikasi menggunakan sonicator. Dispersi larutan $\mathrm{Ca}$ cangkang telur selanjutnya diuji ukuran partikel menggunakan particle size analyzer 
(PSA) sehingga diperoleh ukuran dipelihara pada kandang baterry untuk proses mikropartikel 1,064 $\mu \mathrm{m}$.

Ayam diberi ransum pengamatan dengan diberikan ransum percobaan. Ransum dan air minum diberikan perlakuan selama 21 hari yang dimulai pada umur 15 hari meskipun dipelihara sejak day old chick (DOC). Ayam dipelihara pada kandang litter sampai umur 14 hari, kemudian mulai umur 15 sampai 42 hari ad libitum. Asam sitrat dicampur dengan sedikit porsi ransum $( \pm 25 \mathrm{~g})$ dan diberikan pada pagi hari agar terkonsumsi habis sesuai dengan perlakuan, sebelum diberi ransum tanpa acidifier untuk kebutuhan sehari.

Tabel 1. Komposisi dan kandungan nutrisi ransum penelitian

\begin{tabular}{lccccc}
\hline \multirow{2}{*}{ Bahan Pakan } & \multicolumn{5}{c}{ Komposisi (\%) } \\
\cline { 2 - 6 } Jagung Giling & $\mathrm{T} 0$ & $\mathrm{~T} 1$ & $\mathrm{~T} 2$ & $\mathrm{~T} 3$ & $\mathrm{~T} 4$ \\
Bekatul & 46,00 & 50,00 & 50,00 & 50,00 & 50,00 \\
Bungkil Kedelai & 16,00 & 19,00 & 19,00 & 19,00 & 19,00 \\
Tepung Ikan & 27,00 & 23,50 & 23,50 & 23,50 & 23,50 \\
Tp. Cangkang Telur & 10,00 & 5,00 & 5,00 & 5,00 & 5,00 \\
Tp. Cangkang Telur Mikropartikel & 0,00 & 2,00 & 0,00 & 2,00 & 0,00 \\
CaCO 3 & 0,00 & 0,00 & 2,00 & 0,00 & 2,00 \\
Premiks & 0,50 & 0,00 & 0,00 & 0,00 & 0,00 \\
Total & 0,50 & 0,50 & 0,50 & 0,50 & 0,50 \\
\hline Kandungan Nutrisi*: & $\mathbf{1 0 0}$ & $\mathbf{1 0 0}$ & $\mathbf{1 0 0}$ & $\mathbf{1 0 0}$ & $\mathbf{1 0 0}$ \\
Energi Metabolis (kkal/kg)** & & & & & \\
Protein Kasar* & 2962,55 & 2907,68 & 2907,68 & 2907,68 & 2907,68 \\
Lemak Kasar* & 21,30 & 18,18 & 18,18 & 18,18 & 18,18 \\
Serat Kasar* & 2,87 & 2,14 & 2,14 & 2,14 & 2,14 \\
Kalsium* & 4,57 & 4,45 & 4,45 & 4,45 & 4,45 \\
Fosfor* & 1,03 & 1,29 & 1,29 & 1,29 & 1,29 \\
Metionin*** & 0,53 & 0,53 & 0,53 & 0,53 & 0,53 \\
Lisin*** & 0,45 & 0,35 & 0,35 & 0,35 & 0,35 \\
Arginin*** & 1,37 & 1,05 & 1,05 & 1,05 & 1,05 \\
\hline Keryyyyyy (, & 1,52 & 1,26 & 1,26 & 1,26 & 1,26 \\
\hline
\end{tabular}

Keterangan:

*Dianalisis di Laboratorium Ilmu Nutrisi dan Pakan, Fakultas Peternakan dan Pertanian, Universitas Diponegoro (2017)

**EM $(\mathrm{kkal} / \mathrm{kg})=40,81[0,87$ (protein kasar + 2,25 x lemak kasar + BETN) + k] (Balton, 1967 dalam Siswohardjono, 1995)

***Berdasarkan Tabel dari Komposisi Bahan Makanan Ternak untuk Indonesia (Hartadi et al.,2005

\section{Kecernaan Protein}

Kecernaan protein diukur selama 4 hari mulai hari ke 38 sampai 41 dengan metode total koleksi kombinasi tanpa dipuasakan dengan penambahan indikator $\mathrm{Fe} 2 \mathrm{O} 3$ sebagai penanda. Total koleksi menggunakan 1 ekor ayam untuk setiap ulangan dan 5 ekor ayam dengan umur sama sebagai kelompok non perlakuan untuk koreksi endogenus. Kelompok ayam untuk koreksi endogenus dipuasakan selama 2 hari dengan hanya diberi air minum. Eksreta ditampung dalam nampan yang dilapisi plastik, dan 2 jam sekali di semprot dengan $\mathrm{HCl} 0,2 \mathrm{~N}$ untuk mengikat nitrogen agar tidak menguap. Eksreta dibersihkan dari rontokan bulu dan ceceran ransum kemudian bobot basah ditimbang. Selanjutnya, dijemur sampai kering dan ditimbang untuk memperoleh bobot kering Sampel eksreta yang sudah kering kemudian dihaluskan menggunakan mortar dan lumpang 
selanjutnya dianalisis di Laboratorium untuk mengetahui kandungan protein untuk menghitung kecernaan protein dengan menggunakan rumus McDonald et al. (1988) sebagai berikut:

Kecernaan protein $(\%)$

$=\frac{\text { konsumsi protein }- \text { protein ekskreta }}{\text { konsumsi protein }} \times 100 \%$

\section{Massa Kalsium (Ca) Daging dan Massa Protein Daging}

Massa kalsium (Ca) dan protein daging masing-masing dihitung dari kandungan protein dan kalsium daging dikalikan dengan bobot daging keseluruhan. Sampel daging didapat dari 1 ekor karkas setiap ulangan. Daging dipisahkan (villet) dari tulang kemudian timbang. Daging dicampur merata, dihomogenkan dan dihaluskan dengan blender kemudian diambil $50 \mathrm{~g}$ sampel untuk analisis kandungan $\mathrm{Ca}$ dan protein. Massa kalsium dan protein daging dihitung berdasar rumus Suthama (2003) yaitu:

Massa kalsium atau protein daging $(\mathrm{g})=$ kadar kalsium atau protein daging segar (\%) $\mathrm{x}$ bobot daging $(\mathrm{g})$.

Penelitian dilaksanakan menggunakan rancangan acak lengkap
(RAL) dengan 5 perlakuan dan 4 ulangan, setiap ulangan terdiri dari 8 ekor. Perlakukan yang diterapkan sebagai berikut:

$\mathrm{T} 0=$ ransum dengan protein $21 \%$

$\mathrm{T} 1=$ ransum dengan protein $18 \%$

$\mathrm{T} 2=$ ransum dengan protein $18 \%$ menggunakan mikropartikel tepung cangkang telur $2 \%$

$\mathrm{T} 3=$ ransum dengan protein $18 \%+$ asam sitrat $1,2 \%$

$\mathrm{T} 4=$ ransum dengan protein $18 \%$ menggunakan mikropartikel tepung cangkang telur $2 \%+$ asam sitrat $1,2 \%$

Data dianalisis dengan menggunakan sidik ragam untuk mengetahui pengaruh perlakuan. Apabila terdapat pengaruh nyata, dilanjutkan dengan uji wilayah ganda Duncan pada taraf 5\%. (Steel dan Torrie, 1991).

\section{HASIL DAN PEMBAHASAN}

Ransum menggunakan kalsium organik dari tepung cangkang telur yang dibuat mikropartikel dengan tambahan asam sitrat sebagai acidifier berpengaruh nyata $(\mathrm{P}<0,05)$ terhadap kecernaan protein, massa kalsium dan massa protein daging pada ayam broiler (Tabel 2).

Tabel 2. Kecernaan protein, massa protein dan massa kalsium daging ayam broiler yang diberi ransum menggunakan $\mathrm{Ca}$ mikropartikel dengan ditambah asam sitrat

\begin{tabular}{lccccc}
\hline \multirow{2}{*}{ Parameter } & \multicolumn{5}{c}{ Perlakuan } \\
\cline { 2 - 6 } & $\mathrm{T} 0$ & $\mathrm{~T} 1$ & $\mathrm{~T} 2$ & $\mathrm{~T} 3$ & $\mathrm{~T} 4$ \\
\hline Kecernaan protein (\%) & $80,55^{\mathrm{bc}}$ & $83,88^{\mathrm{b}}$ & $81,01^{\mathrm{bc}}$ & $78,55^{\mathrm{c}}$ & $89,43^{\mathrm{a}}$ \\
Massa kalsium daging (g) & $19,06^{\mathrm{a}}$ & $16,31^{\mathrm{b}}$ & $17,07^{\mathrm{b}}$ & $17,61^{\mathrm{b}}$ & $13,40^{\mathrm{c}}$ \\
Massa protein daging (g) & $75,27^{\mathrm{b}}$ & $76,83^{\mathrm{b}}$ & $87,64^{\mathrm{a}}$ & $89,06^{\mathrm{a}}$ & $92,74^{\mathrm{a}}$ \\
\hline
\end{tabular}

Keterangan : Superskrip berbeda pada baris yang sama menunjukkan perbedaan yang nyata $(\mathrm{P}<0,05)$

\section{Kecernaan Protein}

Ransum T4 (ransum PK 18\% dengan Ca mikro $2 \%$ + asam sitrat $1,2 \%$ ) nyata $(\mathrm{P}<0,05)$ paling tinggi sedangkan perlakuan T3 (ransum PK 18\% dengan Ca makro 2\% + asam sitrat $1,2 \%$ ) paling rendah (Tabel 2). Penambahan asam sitrat pada T4 dapat menyebabkan $\mathrm{pH}$ saluran penceranaan ayam broiler menjadi rendah. Kecernaan protein sangat erat hubungannya dengan dampak dari kesehatan saluran pencernaan akibat pemberian asam sitrat sebagai acidifier. Hal ini didukung oleh data hasil penelitian Kurniawan et al. (2018) bahwa populasi bakteri asam laktat (BAL) tertinggi pada ransum $\mathrm{PK} 18 \%$ dengan Ca mikro $2 \%+$ 
asam sitrat $1,2 \%$ yaitu $5,84 \log \mathrm{CFU} / \mathrm{g}$ dan populasi bakteri coliform terendah yaitu 2,65 $\log$ CFU/g. Perbaikan keseimbangan bakteri dalam usus dapat mempengaruhi fungsi dan kesehatan usus menjadi lebih baik sehingga dapat meningkatkan kecernaan protein. Asam sitrat sebagai acidifier mampu menurunkan $\mathrm{pH}$ usus. $\mathrm{pH}$ rendah menyebabkan bakteri patogen menurun dan bakteri asam laktat (BAL) meningkat, sehingga saluran pencernaan menjadi sehat. Mountzouris et al. (2010) menyatakan bahwa bakteri yang menguntungkan seperti BAL berdampak pada perbaikan keseimbangan mikroba dalam saluran pencernaan, memperbaiki fungsi dan kesehatan saluran pencernaan sehingga terjadi peningkatan pencernaan nutrisi, khususnya protein dan kalsium. Jamilah et al. (2013) menyatakan bahwa asam sitrat merupakan asam organik yang bermanfaat sebagai acidifier dan dapat mengasamkan saluran pencernaan sehingga menekan perkembangan bakteri patogen yang berdampak positif terhadap peningkatan nilai kecernaan. Kondisi asam dan terhambatnya pertumbuhan bakteri patogen dapat meningkatkan kesehatan saluran pecernaan sehingga berdampak pada perbaikan pencernaan nutrisi, terutama protein dan mineral. Fenomena ini terjadi pada perlakuan T4 yang menunjukkan kecernaan protein paling tinggi $(89,43 \%)$ pada Tabel 2.

\section{Massa Kalsium dan Protein Daging}

Penggunaan kalsium organik mikropartikel dengan penambahan asam sitrat nyata $(\mathrm{P}<0,5)$ menurunkan massa kalsium daging pada ayam broiler. Sebaliknya, massa kalsium daging pada perlakuan ransum $21 \%$ protein dengan sumber $\mathrm{Ca}$ non-mikropartikel (T0) menunjukkan nilai paling rendah (Tabel 2), tetapi antara T1, T2, dan T3 tidak berbeda. Massa kalsium daging pada perlakuan T0 $(19,06 \mathrm{~g})$ lebih tinggi dibanding dengan T4 $(13,40 \mathrm{~g})$. Rendahnya massa kalsium daging pada perlakuan T4 yang menggunakan kalsium organik mikropartikel dan asam sitrat disebabkan kalsium lebih banyak diseposisikan ke dalam tulang dibandingkan kedalam daging. Pemberian asam sitrat mampu meningkatkan kalsium dalam darah, namun kalsium bukan berbentuk ion tetapi dalam bentuk kalsium-sitrat (Jamilah et al., 2013). Fenomena ini dapat diasumsikan bahwa kalsium dalam bentuk mikropartikel yang dimediasi oleh asam sitrat lebih mudah diposisi ke dalam tulang. Massa kalsium daging yang didominasi oleh kalsium dalam bentuk ion dapat meningkatkan aktivitas ensim protease dalam daging yang disebut calcium activated neutral protease (CaNP). Sebagaimana diketahui bahwa ion $\mathrm{Ca}$ bebas merupakan aktivator enzim CaNP (Suzuki et al., 1987), dan terkait dengan sekresi Nmetilhistidina sebagai indek dari degradasi protein daging (Suthama, 2006).

Apabila dikaitkan dengan massa protein daging pada penelitian ini ternyata perlakuan $\mathrm{T} 2$, T3 dan $\mathrm{T} 4$ nyata $(\mathrm{P}<0.05)$ lebih tinggi dibandingkan dengan perlakuan T0 dan T1 (Tabel 2). Namun, perlakuan T4 menunjukkan fenomena yang spesifik yaitu massa protein daging tinggi dengan massa kalsium daging paling rendah. Ini memberikan arti bahwa massa kalsium daging rendah dengan keberadaan ion kalsium bebas juga rendah sehingga tidak "provokatif" terhadap aktivitas degradasi enzim CaNP. Bila kederadaan kalsium ion bebas dalam jumlah rendah maka mengurangi degradasi protein yang mengakibatkan massa protein daging meningkat. Suzuki et al. (1987) menyatakan bahwa kalsium daging dalam bentuk ion bebas menurun maka massa protein daging meningkat, karena memicu peningkatan aktivitas enzim CaNP yang pada akhirnya degradasi protein pun meningkat.

Peningkatan kecernaan protein pada perlakuan T4 dapat menjadi faktor pendukung kuat terhadap meningkatnya massa protein daging karena asupan protein merupakan substrat untuk proses sintesis protein. Efek acidifier berupa asam sitrat dapat menyebabkan penurunan $\mathrm{pH}$ dan meningkatkan kesehatan usus halus sehingga dapat meningkatkan kecernaan dan penyerapan nutrisi, terutama kalsium dan 
protein. Perubahan kondisi usus halus akibat pemberian asam sitrat sangat konsisten dengan penelitian Abdel-Fattah et al. (2008) yang menunjukkan bahwa ransum dengan ditambah asam sitrat dapat meningkatkan kesehatan saluran pencernaan yang ditandai oleh penurunan $\mathrm{pH}$ dan jumlah Eschericia coli, serta meningkatnya populasi BAL. Kalsium selain dapat berikatan dengan sitrat, menurut Akbriani (2013) bahwa transportasi kalsium selalu berhubungan dengan protein yang sering disebut $\mathrm{Ca}$ binding protein (CaBP). Penyerapan CaBP lebih efektif didukung oleh penggunaan tepung cangkang telur dalam bentuk mikropartikel sebagai sumber kalsium organik. Tepung cangkang telur mikropartikel dan sebagai sumber kalsium organik lebih mudah diserap. Protein dan kalsium atau $\mathrm{CaBP}$ selanjutnya ditransportasikan ke jaringan target terutama tulang dan daging yang berdampak pada kualitas jaringan target baik tulang maupun daging. Jamilah et al. (2013) melaporkan bahwa semakin tinggi asupan protein (yang dapat diserap) maka semakin tinggi protein yang dapat diakumulasikan ke dalam daging. Nilai massa protein daging yang semakin tinggi, terutama pada perlakuan T4, menunjukkan bahwa pemanfaatan protein semakin efisien yang dapat didistribusikan ke dalam jaringan tubuh, khususnya daging. Suthama et al. (2010) menyatakan bahwa deposisi protein pada ayam broiler merupakan faktor penting bagi keberhasilan produksi daging dan sangat menentukan kualitas karkas. Jadi, fenomena menarik pada penelitian ini bahwa broiler meskipun diberi ransum dengan protein lebih rendah menghasilkan massa protein daging tetap tinggi karena didukung oleh tingginya asupan protein dibawah pengaruh positip asam sitrat.

\section{KESIMPULAN}

Penggunaan kalsium organik mikropartikel cangkang telur dalam ransum protein $18 \%$ dengan tambahan asam sitrat sebagai acidifier menurunkan massa kalsium daging, akan tetapi dapat meningkatkan nilai kecernaan protein dan massa protein daging.

\section{DAFTAR PUSTAKA}

Abdel-Fattah. S. A., M. H. El-Sanhoury, N. M. El-Mednay dan F. Abdel-Azeem. 2008. Thyroid activity, some blood constituents, organs morphology and performance of broiler chicks fed supplemental organic acids. Int. J. Poult. Sci. 7: 215-222.

Akbriani, A. N. 2013. Massa Protein dan Kalsium Daging pada Ayam Kedu Awal Bertelur yang diberikan Ransum dengan Level Protein berbeda. Fakultas Peternakan dan Pertanian, Universitas Diponegoro, Semarang. (Skripsi).

Jamilah, N. Suthama, dan L.D. Mahfudz. 2013. Peforma produksi dan ketahanan tubuh broiler yang diberi pakan step down dengan penambahan asam sitrat. JITV. 18(4): 251 - 257.

Kurniawan, H., N. Suthama, dan B. Sulistiyanto. 2018. Efek Pemberian Kalsium Organik Mikropartikel Cangkang Telur dan Penambahan Asam Sitrat terhadap Populasi Bakteri Usus dan Produktivitas Ayam Broiler. Prosiding Seminar Nasional Peternakan Kebangkitan 3. Hal : 220227.

McDonald, P. A. Edwards dan J. F. D. Green Haigh. 1994. Animal Nutrition. $4^{\text {th }} \mathrm{Ed}$. Longman Scientific and Technical. Copublishing in The USA with John Wiley and Sons. Inc. New York.

Mentari, S.A., L. D. Mahfudz dan N. Suthama. 2014. Massa Protein dan Lemak Daging pada Ayam Broiler yang diberi Tepung Temukunci (Boensenbergia pandurate ROXB) dalam Ransum. Anim. Agri. J. 3 (2) : 211-220.

Mountzouris, K. C., P. Tsitrikos, I. Palamadi, A. Arvaniti, M. Mohnl, G. Schatzmayr, and K. Fegeros. 2010. Effects of probiotic inclusion levels in 
broiler nutrition on growth performance, nutrient digestibility, plasma immunoglobulins and cecal microflora composition. Poult. Sci. 89 (1): $58-67$.

Safitri, A. I., N. Muslihah dan S. Winarsih. 2015. Kajian penambahan tepung cangkang telur ayam ras terhadap kadar kalsium, viskositas dan mutu organoleptic susu kedelai. Majalah Kesehatan FKUB. 1(3) : 149-160.

Siswohardjono, W. 1982. Beberapa Metode Energi Metabolis Bahan Makanan Ternak pada Itik. Makalah Seminar Fakultas Pasca Sarjana. Institut Pertanian Bogor, Bogor.

Steel, R. G. D dan G. H. Torrie. 1981. Principles and Procedures of Statistics : A Biometrical Approach. McGraw-Hill Book Company, New York, Toronto, London.

Suthama, N. 2003. Metabolisme protein pada ayam kampung periode pertumbuhan yang diberi ransum memakai dedak padi fermentasi. J. Pengembangan. Pet. Trop. Edisi Spesiel. Hal. $44-48$.

Suthama, N. 2006. Kajian aspek "protein turnover" tubuh pada ayam Kedu periode pertumbuhan. Med. Pet. 29(2): 47-53.

Suthama, N., H.I. Wahyuni, dan I. Mangisah. 2010. Laju pertumbuhan berdasarkan degradasi proten tubuh pada ayam kedu dipelihara ex situ. Prosiding Seminar Nasional Tentang Unggas Lokal ke-IV. Semarang 7 Oktober 2010. Fakultas Peternakan Universitas Diponegoro, Semarang. Hal. 138 - 146.

Suzuki, K.S. Ohno, Y. Emori, S. Inajoh, and H. Kawasaki. 1987. Calcium activated neutral protease (CaNP) and its biological and medical implications. Progress Clin. Biochem. J. Medical. 5: 44-63.

Tolba, A.A.H. 2010. Reduction of broiler intestinal pathogenic micro-flora under normalor stressed condition. Egyp. J. Poult. Sci. 30: 249-270.

Yendy, S. A., I. Mangisah, dan B. Sukamto. 2014. Pengaruh penambahan asam sitrat dalam ransum sebagai acidifier terhadap retensi kalsium dan fosfor itik jantan lokal. Anim. Agric. J. 3 (1) : $70-78$.

Zuraida, R, E.S. Rohaeni, dan Z. Hikmah. 2006. Prospek pengusahaan ayam pedaging pada Kotamadya Banjarbaru Kalimantan Selatan: Kasus di Desa Palam Kecamatan Cempaka Kota Banjarbaru Kalimantan Selatan. Seminar Nasional Teknologi Peternakan Dan Veteriner hal : 841-845. 